\title{
Paraniesslia tuberculata gen. et sp. nov., and new records or species of Clypeosphaeria, Leptosphaeria and Astrosphaeriella in Hong Kong freshwater habitats
}

Clement K. M. Tsui ${ }^{1}$

Kevin D. Hyde

I. John Hodgkiss

Centre for Research in Fungal Diversity, Department of Ecology $\mathcal{E}^{\circ}$ Biodiversity, The University of Hong Kong, Pokfulam Road, Hong Kong, China

\begin{abstract}
Paraniesslia tuberculata gen. et sp. nov., Clypeosphaeria uniseptata sp. nov. and Leptosphaeria ginimia sp. nov. are described and illustrated from wood submerged in freshwater habitats in Hong Kong, while Astrosphaeriella stellata is reported as a new record from a river in Hong Kong. Paraniesslia tuberculata has characteristic features of the Niessliaceae, but is unique in producing greenish-brown ascospores with tuberculate ornamentation.
\end{abstract}

Key Words: Aquatic fungi, ascomycetes, lignicolous, streams, systematics

\section{INTRODUCTION}

Submerged woody substrata are important in regulating stream hydraulics and habitats for stream organisms (Triska and Cromack 1980). The lignicolous fungal communities are diverse in taxonomic groups (Shearer 1993, Goh and Hyde 1996) and important in breaking down woody substrates in freshwater ecosystems because they produce wood-decaying enzymes (Wong et al 1998). Our study of fungal biodiversity on submerged wood in streams in Hong Kong (Goh and Hyde 1999, Tsui et al 2000) yielded four interesting ascomycetes, including three new species reported in this paper.

\section{MATERIALS AND METHODS}

Samples of submerged woody substrata were collected from different streams in Hong Kong, taken to the laboratory in plastic bags, and processed following the methods described in Tsui et al (2000). Fungi were isolated using single-spore isolation techniques (Choi et al 1999) and where successful, cultures have been deposited in Hong Kong University Culture Collection (HKUCC).

Accepted for publication March 5, 2001.

${ }^{1}$ Corresponding author, Email: clementsui@hotmail.com

\section{TAXONOMY}

Paraniesslia K. M. Tsui, K. D. Hyde et Hodgkiss, gen. nov.

Perithecia superficialia, pyriformia vel subglobosa, setosa, papillata, ostiolata, periphysata, solitaria vel gregaria, brunnea. Peridium membranaceum pluribus stratis textura angulari compositum, extus visum textura epidermoidea. Setae acutae, rectae, non ramosae, brunneae vel nigrae. Filamenta interascalia septata. Asci unitunicati, octospori, clavati, pedicellati, tenuitunicati, apice truncato, apparatu apicali praediti. Ascosporae uniseriatae imbricatae vel biseriatae, ellipsoideae, 1-septatae, viridifuscae ad brunneae, verrucosae, tunica gelatinosa praesens vel absens.

Perithecia superficial, pyriform to subglobose, papillate, with setae, ostiolate, periphysate, solitary to gregarious, brown. Peridium membranous, textura angularis in longitudinal section, textura epidermoidea in surface view. Setae acute, straight, unbranched, septate, brown or black. Interascal filaments septate. Asci unitunicate, 8-spored, clavate, pedicellate, thinwalled, apex truncate, with a nonamyloid discoid refractive apical apparatus. Ascospores overlapping uniseriate to biseriate, ellipsoidal, 1-septate, verrucose, greenish brown to brown, with or without a mucilaginous sheath.

Etymology. From Latin, Paraniesslia, refers to the resemblance to Niesslia.

Species typica. Paraniesslia tuberculata K. M. Tsui, K. D. Hyde et Hodgkiss

Paraniesslia tuberculata K. M. Tsui, K. D. Hyde et Hodgkiss sp. nov. $\quad$ Figs. 1-12

Ascomata 100-130 $\mu \mathrm{m}$ alta, 100-120 $\mu \mathrm{m}$ diam, partim superficialia vel superficialia, pyriformia vel subglobosa, setosa, ostiolata, solitaria, pallide brunnea vel brunnea. Peridium 14-20 $\mu \mathrm{m}$ crassum, pluribus stratis textura angulari compositum, extus visum textura epidermoidea, membranaceum. Setae acutae, non ramosae, brunneae. Filamenta interascalia septata, tenuitunicata, deliquescea. Asci 50-60 $\times$ 8-14 $\mu \mathrm{m}$, octospori, clavati, pedicellati, tenuitunicati, apice truncato, apparatu apicali ca $1 \mu \mathrm{m}$ alto $\times 2.5 \mu \mathrm{m}$ diam praediti. Ascosporae 11-14 $\times 4-6 \mu \mathrm{m}$, uniseriatae imbricatae, 1-septatae, oblonge ellipsoideae, ad apices rotundatae, tuberculatae, viridifuscae, immaturae hyalinae.

Ascomata $100-130 \mu \mathrm{m}$ high, $100-120 \mu \mathrm{m}$ in diam, partly superficial to superficial, pyriform or globose to subglobose, short papillate with black setae, ostiolate, solitary, light brown to brown (Figs. 1-2). Peridium 14-20 $\mu \mathrm{m}$ wide, textura epidermoidea in sur- 

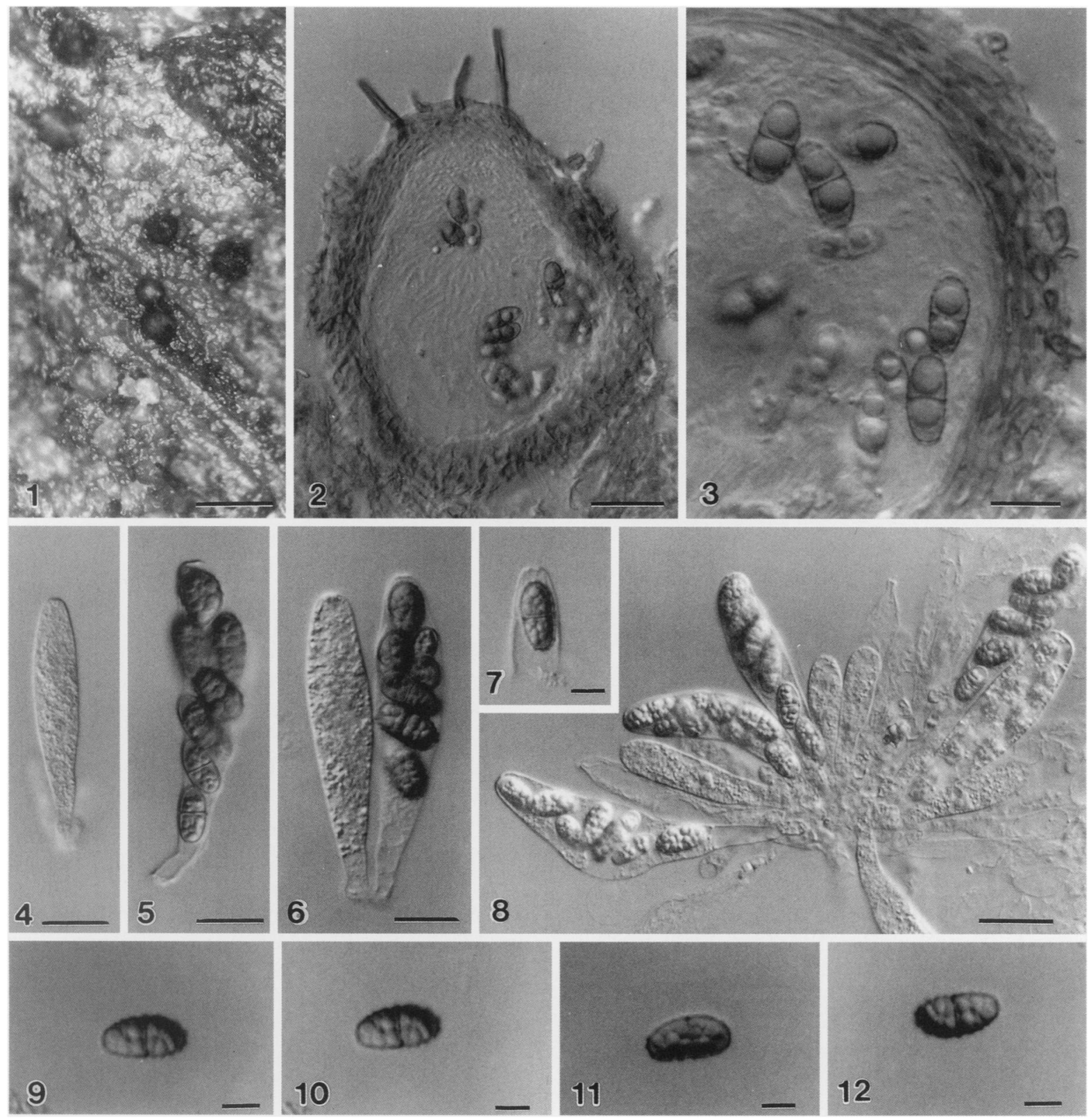

Figs. 1-12. Light (1) and differential interference contrast (2-12) micrographs of Paraniesslia tuberculata (from holotype). 1. Appearance of ascomata on wood. 2. Section of the ascoma. 3. Section of the peridium. 4-7. Asci. Note the discoid apical refractive rings in 7. 8. Asci with paraphyses. 9-12. Ascospores with rough walls. Bars: $1=200 \mu \mathrm{m}, 2=20 \mu \mathrm{m}, 3=$ $8 \mu \mathrm{m}, 4-6=12 \mu \mathrm{m}, 7=5 \mu \mathrm{m}, 8=15,9-12=6 \mu \mathrm{m}$.

face view, and textura angularis in longitudinal section; composed of 3-4 layers of compressed polygonal cells, membranous (FIG. 3). Setae acute, septate, brown (Fig. 2). Interascal filaments septate, thinwalled, deliquescent. Asci 50-75 $\times$ 7-14 $\mu \mathrm{m}(\overline{\mathrm{x}}=60$ $\times 9 \mu \mathrm{m}, \mathrm{n}=15$ ), 8-spored, clavate, short pedicellate, thin-walled, apex truncate, with a discoid refractive apical apparatus, ca $1 \mu \mathrm{m}$ high $\times 2.5 \mu \mathrm{m}$ diam (FIGs. 4-8). Ascospores 11-14 $\times 4-6.5 \mu \mathrm{m}(\overline{\mathrm{x}}=13 \times 5 \mu \mathrm{m}$, $\mathrm{n}=30$ ), overlapping uniseriate, fusoid, ellipsoidal with rounded ends, 1-septate, slightly constricted at septum, ornamented, tuberculate, greenish-brown, hyaline when immature, without a mucilaginous sheath (FIGS. 8-12). No cultures obtained.

Etymology. From tuberculata, in reference to its tuberculate ascospore ornamentation.

Specimens examined. CHINA. HONG KONG: Tai Po, Lam Tsuen River, on submerged wood, Sept 1996, K. M. Tsui, KM 83 (HOLOTYPE, HKU(M) 4647), ibid, Lam Tsuen River, on submerged wood, May 1998, K. M. Tsui, KM 83 (HKU(M) 12152).

Notes. Paraniesslia is placed in the Niessliaceae, 
which accommodates taxa having small, collabent, setose, perithecoid ascomata, unitunicate asci with a nonamyloid, discoid apical apparatus, and uniseptate ascospores (Samuels and Barr 1997). The genera in the Hypocreales have phialidic anamorphs and apical paraphyses, which may appear as deliquescing strands in mature ascomata when they develop from the upper meristematic tissues downwards to the base of the fruiting bodies (Rossman et al. 1999). Although the anamorphs and apical paraphyses were not clearly observed in $P$. tuberculata, the presence of deliquescing interascal filaments and the absence of true paraphyses warrant its disposition in the $\mathrm{Hy}$ pocreales.

The identification of this taxon has been problematic. Using the key of Samuels and Barr (1997), this taxon should belong in either Cryptoniesslia Scheuer or Niesslia Auersw. Paraniesslia tuberculata resembles Cryptoniesslia setulosa Scheuer, in the Niessliaceae, in having inconspicuous, deliquescing interascal filaments found in the centrum. Cryptoniesslia setulosa also differs in having immersed, black ascomata and hyaline, 1-septate, long fusiform ascospores (Scheuer 1993). Niesslia species are characterized by having hyaline, 1-septate ascospores (Barr 1990, 1993), while the ascospores in Paraniesslia tuberculata are verrucose and greenish brown. Paraniesslia is therefore different from the described genera of Niessliaceae (sensu Samuels and Barr 1997).

Another similar genus is Phaeotrichosphaeria Sivan., which produces setose ascomata, unitunicate asci with refractive apical apparatus and brown, 1-septate ascospores (Sivanesan 1983). Phaeotrichosphaeria however is regarded as a relative of Lasiosphaeria Ces. \& De Not. in the Lasiosphaeriaceae, and has thickwalled, noncollabent ascomata, narrow, true paraphyses, and Endophragmiella B. Sutton anamorphs (Sivanesan 1983, Barr 1990). The inclusion of Paraniesslia tuberculata in Savoryella R. A. Eaton \& E. B. G. Jones may be considered. Their shared character is asci that are clavate and possess a discoid apical apparatus. Paraniesslia tuberculata is easily distinguished in having brown, setose ascomata without a neck. The ascospores are greenish brown and ellipsoidal, while Savoryella has black ascomata and brown, 4-septate ascospores with hyaline end cells. Also Savoryella is not closely related to the Niessliaceae and may belong in the Halosphaeriales (Ranghoo pers comm).

Clypeosphaeria uniseptata K. M. Tsui, K. D. Hyde et Hodgkiss, sp. nov.

FIGS. 13-21

Ascomata $150-200 \mu \mathrm{m}$ alta, $400-550 \mu \mathrm{m}$ diam, subglobosa vel applanata, sub clypeo immersa ad partim erumpentia, ostiolata, coriacea, nigra. Papilla conica, periphysata. Peridium ca $20 \mu \mathrm{m}$ crassum, textura angulari. Paraphy- ses ca $5 \mu \mathrm{m}$ crass, filamentos, septati, hyalinae. Asci 120 $160 \times 6-7 \mu \mathrm{m}$, unitunicati, cylindrici, pedicellati, apparatu subapicali iodo caerulescente $(\mathrm{J}+)$ praediti. Ascosporae 14 $20 \times 5-7 \mu \mathrm{m}$, ellipsoideae, uniseriatae imbricatae, bicellulares, constrictae ad septum, laeves, crassitunicatae, pallide brunneae.

Ascomata 150-200 high, 400-550 diam, subglobose or applanate, erumpent to partly immersed beneath a clypeus, ostiolate, coriaceous, black (FIGs. 13, 14). Papilla conical, periphysate (FIG. 14). Peridium ca 20 $\mu \mathrm{m}$ wide, textura angularis, composed of several layers of brown, compressed angular cells (FIG. 15). Paraphyses ca $5 \mu \mathrm{m}$ wide, mostly longer than asci, filamentous, septate, hardly found. Asci 120-160 × 6-8 $\mu \mathrm{m}(\overline{\mathrm{x}}=126 \times 6.5 \mu \mathrm{m}, \mathrm{n}=25)$, unitunicate, long cylindrical, pedicellate, with a $\mathrm{J}+$, discoid, sub-apical ring (FIGs. 16, 17). Ascospores 14-19 $\times 5-7 \mu \mathrm{m}(\overline{\mathrm{x}}$ $=16 \times 6 \mu \mathrm{m}, \mathrm{n}=40$ ), overlapping uniseriate, ellipsoidal, 1-septate, slightly constricted at septum, smooth, thick-walled, pale brown (FIGS. 18-21).

Colonies on potato dextrose agar fast growing, with superficial white hyphae, cottony and flat with crenate edges, white reverse. No conidia or conidiophores produced.

Etymology. From uniseptata, in reference to the 1septate ascospores.

Specimens examined. CHINA. HONG KONG: Tai Po, Lam Tsuen River, on submerged wood, Sep 1997, K. M. Tsui, KM 247 (HOLOTYPE, HKU(M) 8095), cultures from holotype (HKUCC 6579).

Notes. Species in Clypeosphaeria Fuckel have clypeate, conspicuously papillate ascomata, long cylindrical asci with subapical, amyloid rings and uniseriate, ellipsoidal, brown ascospores. This genus was discussed by Barr (1989) and three species, C. mamillana (Fr.) Lamb., C. perfidiosa (De Not.) Barr and $C$. americana Barr \& Samuels were included. The genus is now considered to be monotypic because $C$. perfidiosa and C. americana were transferred to Stereosphaeria Kirschst. (Hyde et al 1998). Clypeosphaeria mamillana has a wedge-shaped subapical ring as compared to discoid in C. uniseptata and thin-walled ascospores that have one septum near the base (Barr 1989), or have 5 pseudosepta (Hyde et al 1998), as compared to 1 septum in C. uniseptata.

Species in Amphisphaeria Ces. \& De Not. also have clypeate ascomata, long cylindrical asci with amyloid, subapical discoid rings, and ellipsoidal, 1-septate, brown ascospores (Barr 1990), and are characterized by having Pestalotia-like anamorphs (Kang et al 1999). We found no evidence of Pestalotia-like anamorphs in cultures of $C$. uniseptata, and its characteristic ascomatal morphology warrant the placement of this taxon in Clypeosphaeria. Clypeosphaeria uniseptata resembles Amphisphaeria pakistane E. Müll. \& 

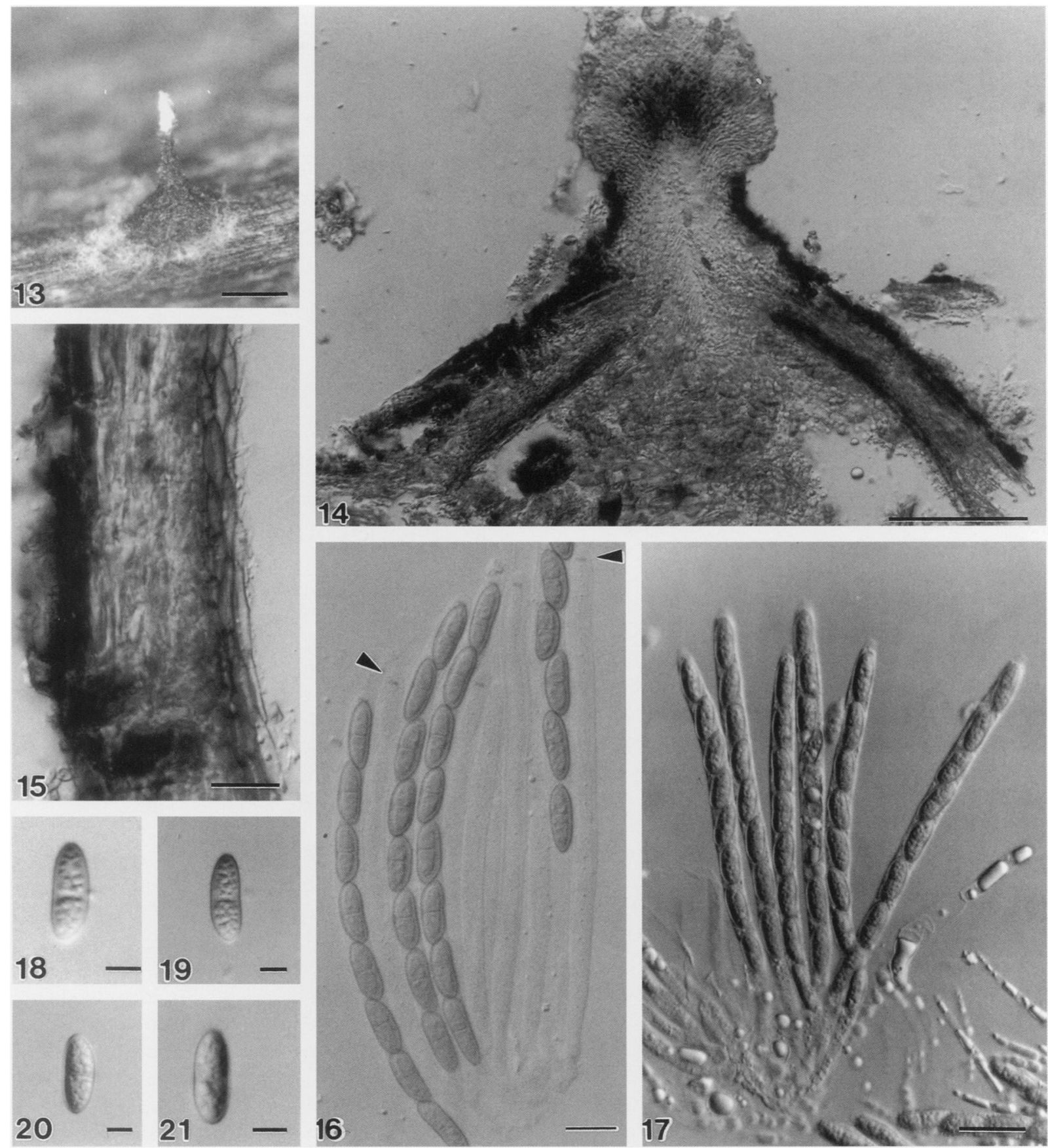

FiGs. 13-21. Light (13) and differential interference contrast (14-21) micrographs of Clypeosphaeria uniseptata (from holotype). 13. Appearance of ascomata on wood. 14. Section of the ascoma. 15. Section of the peridium. 16-17. Asci with inconspicuous interascal filaments. Note the amyloid discoid subapical apparatus (stained). 18-21. Ascospores. Scale bars: 13 $=300 \mu \mathrm{m}, 14=100 \mu \mathrm{m}, 15=15 \mu \mathrm{m}, 16-17=10 \mu \mathrm{m}, 18-21=5 \mu \mathrm{m}$.

Ahmad [ZT 9032, holotype] in producing ellipsoidal, brown, 1-septate ascospores, but is unique in having thick-walled ascospores.

\section{Leptosphaeria ginimia K. M. Tsui, K. D. Hyde et Hodgkiss, sp. nov. Figs. 22-30}

Ascomata 240-300 $\mu \mathrm{m}$ alta, 200-300 $\mu \mathrm{m}$ diam, erumpentia, superficialia vel partim immersa, subglobosa vel globosa, gregaria, ostiolata, atrobrunnea vel nigra. Paries ascomatis bistratus, $20-30 \mu \mathrm{m}$ crassus, stratum internum e textura angulari; stratum externum cellulis scleroparenchymaticis, 6 $8 \times 3-6 \mu \mathrm{m}$, atrobrunneis, compressis compositum. Pseudoparaphyses numerosae, ca $2 \mu \mathrm{m}$ crassae, septatae, filamentosae. Asci 100-130 × 10-15 $\mu \mathrm{m}, 8$-spori, cylindrici, breve pedicellati, bitunicati, fissitunicati. Ascosporae 27.5$35 \times 6-7.5 \mu \mathrm{m}$, biseriatae, 5-(6)-septatae, fusiformes, ad 

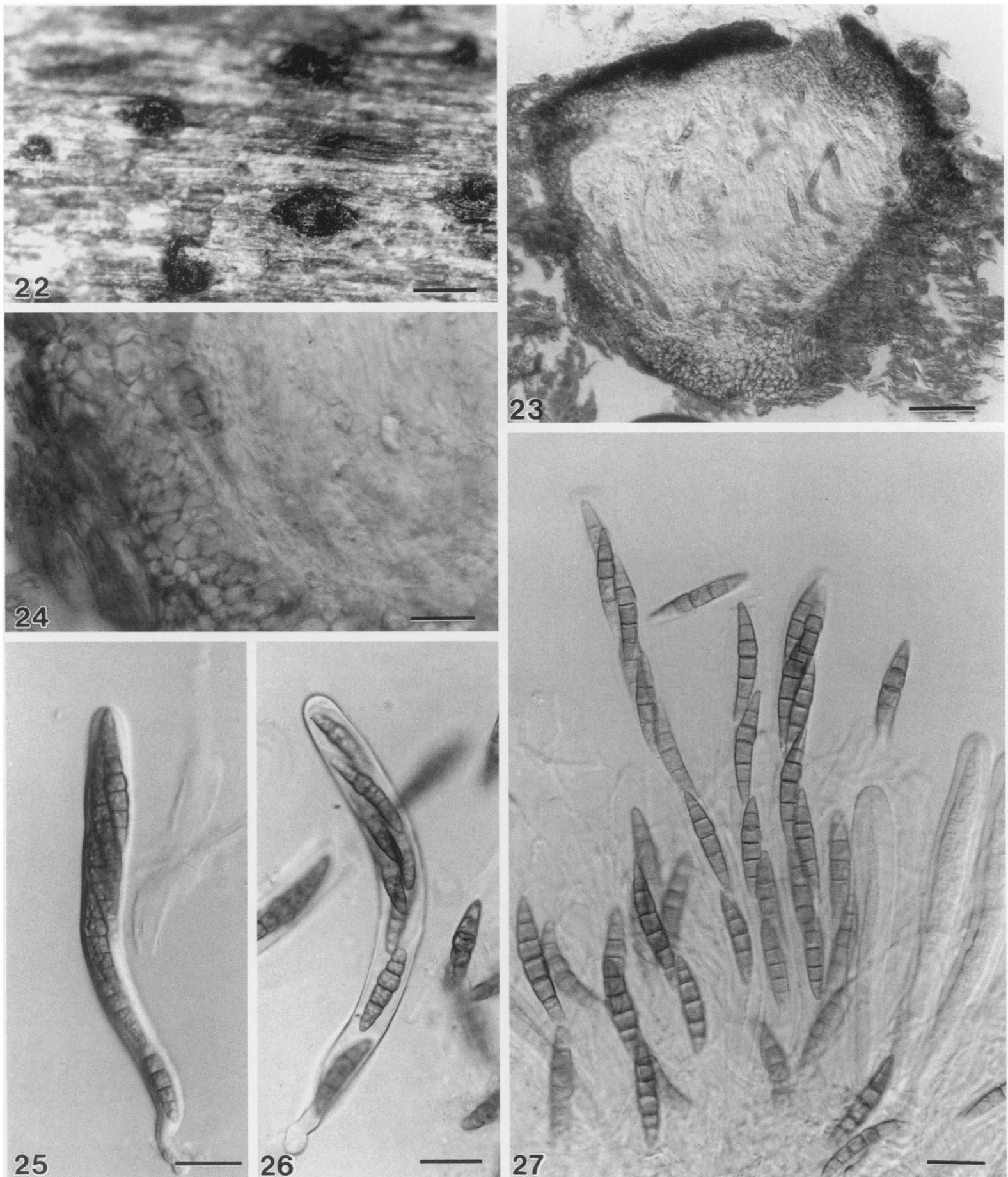

25
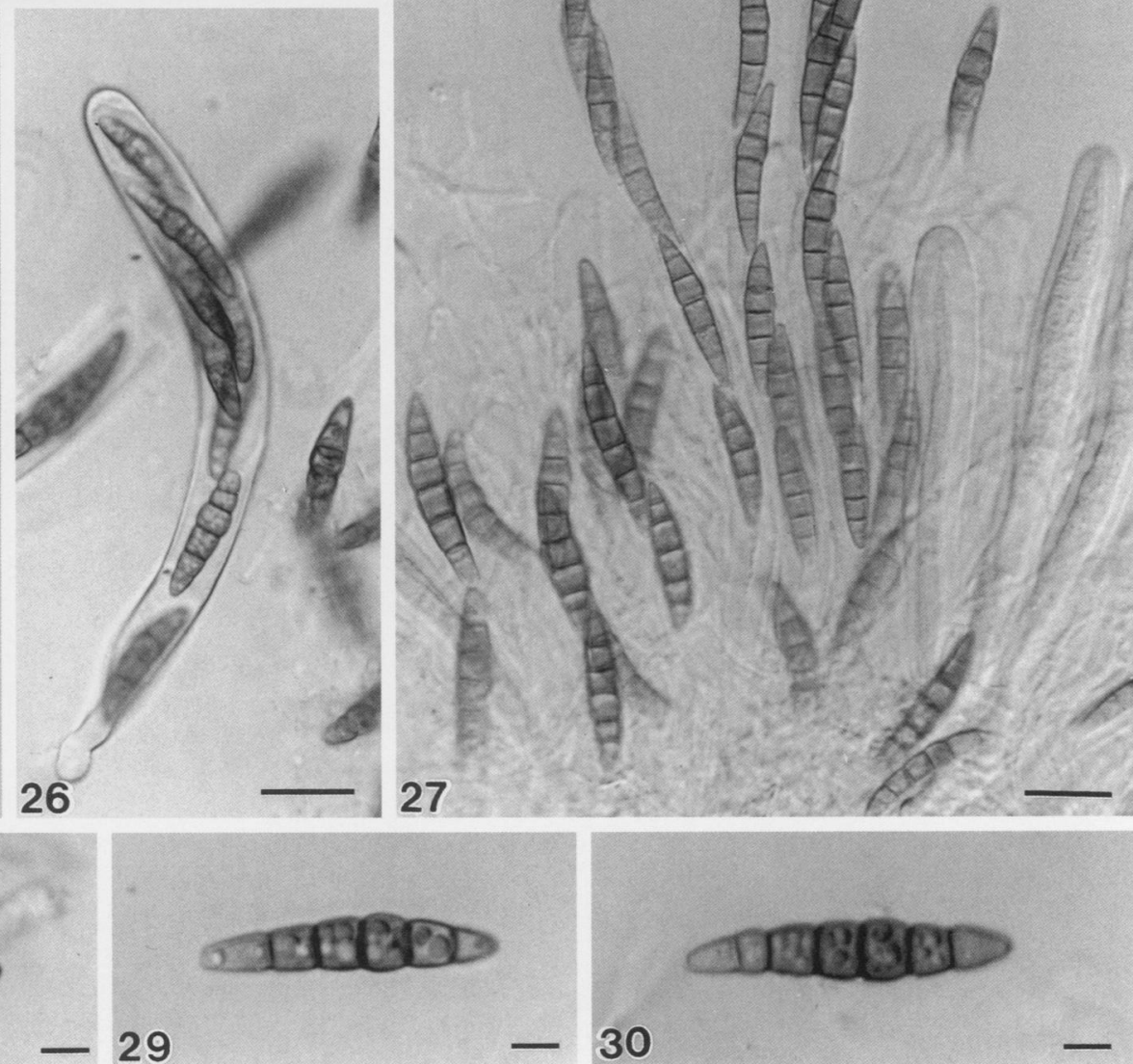

28 29
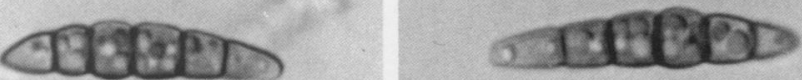

Treores

30

FIGS. 22-30. Light (22) and differential interference contrast (23-30) micrographs of Leptosphaeria ginimia (from holotype). 22. Appearance of ascomata on wood. 23. Section of the ascoma. 24. Section of the peridium. 25-26. Asci. 27. Asci with pseudoparaphyses. 28-30. Ascospores. Scale bars: $22=250 \mu \mathrm{m}, 23=50 \mu \mathrm{m}, 24=10 \mu \mathrm{m}, 25-27=20 \mu \mathrm{m}, 28-30=$ $5 \mu \mathrm{m}$. 

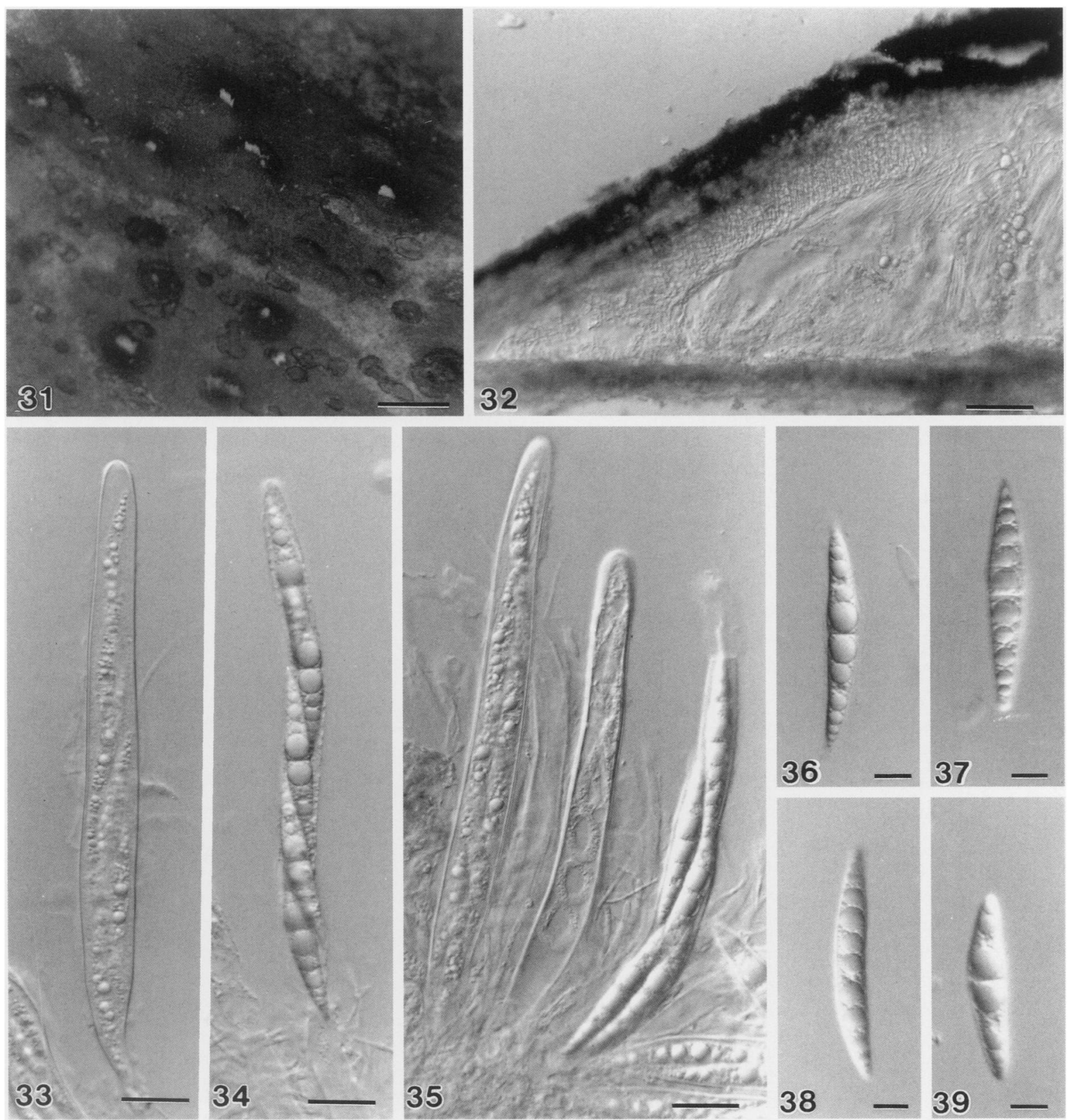

Figs. 31-39. Light (31) and differential interference contrast (32-39) micrographs of Astrosphaeriella stellata [from HKU(M) 16118]. 31. Appearance of ascomata on wood. 32. Section of the ascoma. 33-34. Asci. 35. Asci with pseudoparaphyses. 36-39. Ascospores. Scale bars: $31=900 \mu \mathrm{m}, 32=50 \mu \mathrm{m}, 33=15 \mu \mathrm{m}, 34-35=20 \mu \mathrm{m}, 36-39=8 \mu \mathrm{m}$.

septa constrictae, guttulatae, fulvae vel brunneae, tunica gelatinosa praeditae.

Ascomata $240-300 \mu \mathrm{m}$ high, $200-300 \mu \mathrm{m}$ in diam, erumpent, superficial or partly immersed, subglobose to globose, gregarious, ostiolate, dark brown to black (FIG. 22). Peridium 20-30 $\mu \mathrm{m}$ wide, consisting of two layers: cells of outer layer interpersed with host cells, comprising 3-4 layers of brown polygonal 6-8 $\times$ 3-6 $\mu \mathrm{m}$ scleroparenchymatic cells; inner layer textura angularis (FIGS. 23, 24). Pseudoparaphyses cellular, numerous, ca $2 \mu \mathrm{m}$ wide, septate, filamentous, and embedded in a transparent gelatinous matrix (FIG. 27). Asci 95-140 × 9-13 $\mu \mathrm{m}(\overline{\mathrm{x}}=121 \times 11$ $\mu \mathrm{m}, \mathrm{n}=25$ ), 8-spored, cylindrical, short pedicellate, bitunicate, fissitunicate, ectoascus rupturing at the apex (Figs. 25-27). Ascospores 27.5-35 $\times$ 5.5-7 $\mu \mathrm{m}$ $(\overline{\mathrm{x}}=32 \times 6 \mu \mathrm{m}, \mathrm{n}=35)$, overlapping biseriate, 5 (6)-septate, fusiform, swollen at third cell, constricted at the septa, guttulate, yellow to pale brown, surrounded by a mucilaginous sheath (FIGS. 28-30).

Colonies on potato dextrose agar slow growing, mostly immersed, brown to gray reverse, with super- 
ficial hyphal growth, fluffy, effuse, with dentate edges, producing yellow pigments. No anamorphs produced.

Etymology. The Latin ginimia, derived from Ginimi Chan, for her appreciation and support of first author's work in mycology.

Specimens examined. CHINA. HONG KONG: Tai Po, Lam Tsuen River, on submerged wood, 31 May 2000, K. M. Tsui, KM31 (HOLOTYPE, HKU(M) 16115), culture of holotype (HKUCC 6465), Sep 1996, K. M. Tsui, KM31 (HKU(M) 4613), (HKU(M) 4627), (HKU(M) 5380), Sep 1997, K. M. Tsui, KM31 (HKU(M) 8056), Dec 1998, K. M. Tsui, KM31 (HKU(M) 12193).

Notes. Leptosphaeria Ces. \& De Not. is a heterogeneous genus, and highly resembles Phaeosphaeria Miyake which also produces fusiform to cylindrical, bitunicate asci, and yellow, guttulate ascospores with more than 3 septa (Shoemaker and Babcock 1989). This taxon is better placed in Leptosphaeria (sensu Holm 1957, Shearer et al 1990, Ahn and Shearer 1997) because it possesses a thick ascomatal wall comprising scleroplectenchymatic cells and was collected from woody substrata.

Leptosphaeria tetonensis (Ellis \& Everhart) Rehm resembles $L$. ginimia in producing 5 to 6-septate, brown ascospores with enlarged third cells from apex (Shoemaker 1984), but differs in lacking guttules and a mucilaginous sheath. The ascospores in L. ginimia are also yellow to brown while those in L. tetonensis are reddish brown (Shoemaker 1984). This taxon is unique among other species in Leptosphaeria (Müller 1950, Crivelli 1983, Shoemaker 1984). The ascospores in Phaeosphaeria luctuosa (Niessl) Otani \& Mikawa are also 5-septate, yellow, of similar size, and have an enlarged third cell from apex (Webster 1957, Ridley 1988). Phaeosphaeria luctuosa however, has been reported from grass, and produces smaller ascomata with pseudoparenchymatous cells (Ridley 1988) and Phaeoseptoria Speg. and Stagonospora (Sacc.) Sacc. anamorphs (Webster 1957, Leuchtmann 1984).

Astrosphaeriella stellata (Pat.) Sacc., Syll. Fung. 24:938.

FIGS. 31-39

Ascomata 200-250 $\mu \mathrm{m}$ high, 800-950 $\mu \mathrm{m}$ diam, superficial, erumpent, dome-shaped to mammiform, with a flattened base, with slit-like ostiole, gregarious, black (FIGs. 31, 32). Peridium 50-100 $\mu \mathrm{m}$ wide, cells of outer layer with blackish and amorphous material; inner layer composed of thin-walled, polygonal cells, cells are flattened at the base (FIG. 32). Pseudoparaphyses trabeculate, numerous, 2-3 $\mu$ m wide, filamentous, septate (FIG. 35). Asci 150-250 × 13-19 $\mathrm{m}$ ( $\overline{\mathrm{x}}$ $=188 \times 15 \mu \mathrm{m}, \mathrm{n}=20$ ), bitunicate, fissitunicate, ectoascus rupturing at the apex, 8-spored, cylindrical to cylindric-clavate, pedicellate, (FIGS. 33-35). Asco- spores $48-60 \times 7-9 \mu \mathrm{m}(\overline{\mathrm{x}}=55 \times 7.5 \mu \mathrm{m}, \mathrm{n}=35)$, overlapping uni- to biseriate, 1 -septate, elongate fusiform, guttulate, constricted at the septum, hyaline, surrounded by a mucilaginous sheath (FIGS. 36-39).

Colonies on corn meal agar (CMA) slow growing, reaching $3 \mathrm{~cm}$ diam after two months, superficial hyphal growth low convex, creamy, woolly, white reverse. No anamorphs produced.

Specimens examined. CHINA. HONG KONG: Tai Po, Pak Au Shek, on submerged bamboo in the Lam Tusen River, Aug 1998, K. M. Tsui Ev Jackie Chan, KM 287 [HKU(M) 16118, culture (HKUCC 6856)], May 2000, K. M. Tsui, KM287 (HKU(M) 16113).

Notes. The placement of this taxon in Astrosphaeriella Syd. et P. Syd. is suitable because it has trabeculate pseudoparaphyses and hyaline, elongate fusiform ascospores with mucilaginous sheaths. The genus has also been expanded to include species with a slit-like ostiole (Hyde et al 2000) but this character has not been reported from collections of $A$. stellata on terrestrial bamboo (Hawksworth 1981) and palms (Hyde and Fröhlich 1997).

\section{ACKNOWLEDGMENTS}

We are grateful to Dr. C. Scheuer and the anonymous reviewer for the comments on the manuscript. Drs. C. Shearer, G. Samuels, and Y. Z. Wang are thanked for the advice on the identification of ascomycetes. K. M. Tsui thanks The University of Hong Kong for the award of a Postgraduate Studentship. Helen Leung, Ken Wong and A. Y. P. Lee are thanked for their technical and photographic assistance.

\section{LITERATURE CITED}

Ahn Y-M, Shearer CA. 1997. Reexamination of taxa in Leptosphaeria originally described on host species in Ranunculaceae, Papaveraceae, and Magnoliaceae. Can J Bot 76:258-280.

Barr ME. 1989. Clypeosphaeria and the Clypeosphaeriaceae. Syst Ascomy 8:1-8.

. 1990. Prodromus to non-lichenized, pyrenomycetous members of class Hymenoascomycetes. Mycotaxon 39:43-184.

- 1993. Redisposition of some taxa described by J. B. Ellis. Mycotaxon 46:45-76.

Choi YW, Hyde KD, Ho WH. 1999. Single spore isolation of fungi. Fung Divers 3:29-38.

Crivelli PG. 1983. Über die heterogene Ascomycetungattung Pleospora Rabh.; Vorschlag für eine Aufteilung. Diss. ETH Nr. 7318. Flück-Wirth, Komm.-Verl., Teufen. $213 \mathrm{p}$.

Goh TK, Hyde KD. 1996. Biodiversity of freshwater fungi. J Industr Microbiol 17:328-345.

1999. Fungi on submerged wood and bamboo in the Plover Cove Reservoir, Hong Kong. Fung Divers 3:57-85.

Hawksworth DL. 1981. Astrosphaeriella Sydow, a misunder- 
stood genus of melannomataceous pyrenomycetes. Bot J Linn Soc 82:35-59.

Holm L. 1957. Études taxonomiques sur les Pléosporacés. Symb Bot Upsal 14:1-188.

Hyde KD, Fröhlich J. 1997. Fungi from palms. XXXVII. The genus Astrosphaeriella, including ten new species. Sydowia 50:81-132.

- - $\longrightarrow$ Taylor JE. 1998. Fungi from palms. XXXVI. Reflections on unitunicate ascomycetes with apiospores. Sydowia 50:21-80.

, Aptroot A, Fröhlich J, Taylor JE. 2000. Fungi from palms. XLIII. Lophiostoma and Astrosphaeriella species with slit-like ostioles. Nova Hedwigia 70:143-160.

Kang JC, Hyde KD, Kong RYC. 1999. Studies on Amphisphaeriales: the Amphisphaeriaceae (sensu stricto). Mycol Res 103:53-64.

Leuchtmann A. 1984. Über Phaeosphaeria Miyake und andere bitunicate Ascomyceten mit mehrfach querseptierten Ascosporen. Sydowia 37:75-184.

Müller E. 1950. Die schweizerischen Arten der Gattung Leptosphaeria und ihrer Verwandten. Sydowia 4:185-319.

Ridley GS. 1988. New records and species of Loculoascomycetes from New Zealand. New Zealand J Bot 26:409422.

Rossman AY, Samuels GJ, Rogerson CT, Lowen R. 1999. Genera of Bionectriaceae, Hypocreaceae and Nectriaceae (Hypocreales, Ascomycetes). Stud Mycol 42:248.

Samuels GJ, Barr ME. 1997. Notes on and additions to the Niessliaceae (Hypocreales). Can J Bot 75:2165-2176.
Scheuer C. 1993. Cryptoniesslia setulosa gen. et sp. nov. Mycol Res 97:543-546.

Shearer CA. 1993. The freshwater ascomycetes. Nova Hedwig 56:1-33.

— Crane JL, Reddy CKR. 1990. Studies in Leptosphaeria. Lectotypification of Sphaeria doliolum. Mycologia 82:496-500.

Shoemaker RA. 1984. Canadian and some extralimital Leptosphaeria species. Can J Bot 62:2688-2729.

—, Babcock CE. 1989. Phaeosphaeria. Can J Bot 67: 1500-1599.

Sivanesan A. 1983. Studies on ascomycetes. Trans Brit Mycol Soc 81:313-332.

Triska FJ, Cromack K. 1980. The role of wood debris in forests and streams. In: Waring $\mathrm{RH}$, ed. Forest: fresh perspectives from ecosystem analysis. Proc $40^{\text {th }}$ Biol Colloq 1979. Corvallis, Oregon: Oregon University Press. p 171-190.

Tsui CKM, Hyde KD, Hodgkiss IJ. 2000. Biodiversity of fungi on submerged wood in Hong Kong streams. Aqua Microb Ecol 21:289-298.

Webster J. 1957. Graminicolous pyrenomycetes. IV. Conidia of Ophiobolus herpotrichus, Leptosphaeria luctuosa, L. fuckelii, L. pontiformis and L. eustomoides. Trans Brit Mycol Soc 40:509-522.

Wong MKM, Goh TK, Hodgkiss IJ, Hyde KD, Ranghoo VM, Tsui CKM, Ho W-H, Wong WSW, Yuen T-K. 1998. Role of fungi in freshwater ecosystem. Biodiv Conserv 7: 1187-1206. 